\title{
IE Comic in Primary School
}

\author{
Eni Fariyatul Fahyuni \\ Fakultas Agama Islam \\ Universitas Muhammadiyah Sidoarjo \\ Sidoarjo, Indonesia \\ eni.fariyatul@umsida.ac.id
}

\author{
Ida Rindaningsih \\ Fakultas agama Islam \\ Universitas Muhammadiyah Sidoarjo \\ Sidoarjo, Indonesia
}

\author{
Istikomah Istikomah \\ Fakultas Agama Islam \\ Universitas Muhamadiyah Sidoarjo \\ Sidoarjo, Indonesia
}

\begin{abstract}
Using Islamic Education (IE) comic in primary school is an alternative way for teachers to deliver materials or concept of Islamic knowledge that can build students' good characters. This study aims to describe the role of IE in fulfilling students' needs to accept certain codes of behavior which give benefit for their positive activities either in the school or family life. The design of the comic has been assessed in terms of its effectiveness, efficiency and attractiveness to enhance the quality of teaching and learning process. This study found that IE comic is relevant and easy for teaching and learing practice. The implementation was performed by clarifying and internalizing the values and characters that suit with the subject matter using questions and answers techniques; contextual art; stories; case analysis; mutual respect and understanding others.
\end{abstract}

Keywords-Islamic education comic; moral values; primary school

\section{INTRODUCTION}

In primary school, students seem to have some difficulties in explaining the concepts of Islamic education. Teachers have limited access for searching related materials. The educators provide textbook and use it without any modification from authentic supplememntary sources. Teachers tend to have limited creativity in planning and preparing the classroom activities with innovations that potentially attract the attention and motivation. This is certainly a serious problem that need concrete solution. Developed IE comic exhibit relationship narration and image. "....that visual illustrations with text in harmony enable understanding the issues better" [1]. Education Comics are considered good for citizenship and democracy education [2]. An ideal comic is designed with three citeria: understandable, memorable, and enjoyable in order to enhance their literacy [3].

Comics stimulate learner's reading interest [4]. Literacy has more important influence at the daily life [5]. Students have found the ability and complete tasks [6] [7]. Comics combine pictorial images and words to transmit stories and messages [8]. Comics also has feature for improving students' language skill [9]. That education value improve quality in primary school [10].

Developing IE comic is considered effective to increase students' achievement by peers or teachers. IE comic concerns on the oneness of God and truth habit of good or bad character in daily activity to explore the students' ideas in expressing their thinking and trying to solve problems based on the Quran. Islamic education trins people to have balance in physical, emotional, spiritual, and intellectuals. The IE comic is believed to change one's belief and values as well as reduce unwanted deviant behaviors. Students will not only respect their own behaviors, but also participate in collective monitoring and evaluation towards their friends' behaviors by the current condition of Indonesia. Education should have early awareness to organize, discover, and construct what is happening through observing and finding the accountable solution in shaping young generation character.

\section{METHOD}

The method of this research is research and development (R\&D). This study focuses on developing comic with Islamic values entitled "Senangnya Bisa Bersedekah" which tells about the happy feeling to be able to give alms or charity to others. It is written in Indonesia language. This study adapted Dick and Carey model. The model used only ninth step [11]. The data collected in this study is both quantitative and qualitative data. The methods of data collection used are documentation record, questionnaires, and written test. Then, the data were collected from those instruments then analyzed in descriptive qualitative, descriptive quantitative, and inferential statistical analysis (T-test).

\section{RESULTS AND DISCUSSION}

Students in primary school are generally more interested reading books with pictures of attractive, and colourless. Comic can help replace boredom, and it supports the role of learning activities with two-way learning process that becomes significant condition in teaching and learning process. Furthermore, the responsibilities as an educator needs to be 
grounded through religious teaching, according to the word of Allah in Quran.

[We sent them] with clear proofs and written ordinances. And We revealed to you the message that you may make clear to the people what was sent down to them and that they might give thought (An-Nahl verse 44) [12].

The development of IE comic consisiting of 12 pages covers at least three criteria: validity, practicality and effectiveness. Messages with words and illustrations using by readers imagination between the pictures [13]. Validity content of IE comic linier with the purpose learning includes two major: (1) based on theoretical rationale; and (2) consistency internal. The expert validation IE comic by reviewer advice of comics. The value of learning medium perceptions of $89 \%$ to category of very interesting in primary schools. IE comic contains moral values reflected through the attractive pictures can be easily into a good story. Picture story book related to be a systematic story [14].

The practicality IE comic can be applied and validation material expert by reviewer of the Islamic education in primary school. The value perception of the learning material obtained value of $93 \%$, which means included very interesting as medium instruction. The use aqeedah morals comic increase reading interest and positive appreciation from learners [15]. Reading interest has strong positive for relationship growth reading to vocabulary, comprehension, fluency development [16].

The findings of this study mention that ZPD is potential to enhance language development and information effectively and efficiently when learners were asked to tell a story based on the pictures in the comic. The teacher provided few guide to build cooperative and supportive mood for the readers during the implementation [17].

IE comic is a part of literary work that gives meaningful experience to the teaching and learning process [18]. The effectiveness IE comic to be tested on the scale as widely, conducted individual tests the level of understanding prototype product. The results of the analysis research appropriateness of $95.8 \%$ included interval (100\%) very interesting as a medium of instruction. The small group prototype of the comic was placed the products was applied in the practice of learning at scale unlimited of $93 \%$ included in the category of great interest.

IE comic "Senangnya Bisa Bersedekah" is interesting, and it could stimulate motivation and enthusiasm towards a certain topic in the learning activities. In addition, IE comic with value approach can help students to decide the moral value in a correct and honest way without any force and pressure. IE comic communicated subjects on the values as mentioned through learning innovation. The IE comic encourages students to have awareness towards their own values derive of values education to link value activity. The value clarification to raise their awareness towards their own value students' reflection on anti-social behaviors such as playing truant and changing one's belief and values as well as reducing deviant behaviors [19]. In addition, IE comic as the learning medium with value clarification technique approach can help students decide the moral value in a correct and honest way without any force and pressure.

\section{CONCLUSION}

The average results of the IE comic is $93 \%$, which indicates that in its implementation, IE comic is very interesting or feasible to be used as an instructional medium. $92 \%$ shows that the comic increases interest in reading and raises students' positive appreciation. The results of this study support the cognitive theory of multimedia learning that words presented as narratives, auditory channels can be used for the processing of words. Information processing balanced two channels so there is no one overload. The pictures through the eyes (pictorial processed) and words through the ear (verbal processed).

\section{ACKNOWLEDGEMENT}

This research and development was supported by Universitas Muhammadiyah Sidoarjo, Faculty of Islamic Studies. The headmaster, teachers and students in SD Muhammadiyah Sidoarjo and everyone who participated in this research.

\section{REFERENCES}

[1] Purnell, K. N., \& Solman, R. T. The influence of technical illustrations on students' comprehension in geography. Reading Research Quarterly, 26(3), 277-299. 1991.

[2] Topkaya, Y., \& Şimşek, U. Impact of instructional comics on the attitudes towards citizenship and democracy education. Journal of Computer and Education Research, 3(6), 152-167. doi:10.18009/jcer. 26543. 2015.

[3] Aquiler Negrete. Constructing a Comic to Communicate Scientific Information About Sustainable Development and Natural Resourches in Mexico. Procedia-Social and Behavioral Sciences 103. 200-209. 2013

[4] Ujiie and S.Krashen,"Comic book reading, reading enjoyment, and pleasure reading among middle class and chapter 1 middle school students," Reading Improvment, vol. 33,pp. 51-54, 1996.

[5] Wallace, C. Reading. Oxford: Oxford University Press. 1992.

[6] Norton and K.Vanderheyden, "Comic book culture and second language learners,"in Critical Pedagogies and Language Learning, B. Norton and K. Toohey,Eds.,New York: Cambrige University Press. pp. 201-221. 2004.

[7] Pintrich, "Motivation as an enabler for academic success," School Psychology Review, vol. 31, pp. 313-327, 2002

[8] McCloud, Scott. Memahami media cerita bergambar (terj. S. Kinanti) Jakarta KPG (Kepustakaan Populer Gramedia). 2008.

[9] F. Megawati. Comic Strips: a study on the teaching of writing narrative texts to Indonesian EFL students. Teflin Journal. 23 (2). 183-205. 2012.

[10] Fahyuni, Eni. F \& Adi Bandono. The use of value clarification technique-based- picture story media as an alternative media to value education in primary school. : Journal of Arts Research and Education 17 (1) 68-74. 2017.

[11] Dick, W dan Carey, L The Systematic Design of Instruction. Fifth Edition. New Jersey: Pearson Education Inc. 2009.

[12] https://quran.com/16/44

[13] Rota, G.; Izquierdo, J. Comics as a tool for teaching biotechnology in primary school. Eletronic Journal of Biotechnology, 6 (2). 2003. 
[14] Mitchell, Diana. Children's Literature an Imitation to the Word. Michigan State University. 2003.

[15] Fahyuni, Eni. F \& Imam Fauji. Pengembangan Komik Akidah Akhlak untuk Meningkatkan Minat Baca dan Prestasi Belajar Siswa Sekolah Dasar. Islamic Education Journal 1 (1), Juni 2017, 17-26. 2017.

[16] Anderson, R., Fielding, L., \& Wilson, P. Growth In Reading and How Children Spend Their Time Outside Of School. Reading Research Quarterly, 23, 285-303. http://dx.doi.org/10.1598/RRQ.23.3.2. 1988.

[17] Salam Khaliliaqdam. ZPD, Scaffolding and Basic Speech Development in EFL Context. Procedia Social and Behavioral Science98 891-897. 2014.

[18] F.I.N. Abida, Critical Thinking Skills to Literary Works: A Method of Teaching Language Through Literature. JEES (Journal of English Educators Society), 1(1). 11-18.2016.

[19] Josephine Oliha, and Vivian I. Audu. Effectiveness of Value Clarification and Self-Manangement Techniques in Reducing Droput Tendency Among Secondary Schools Students in Edo State. European Journal of Educational and Development Psychology.Vol.3, No.1, pp.1-13, March 2015. 